\title{
New Alkaline Copper Electroplating Bath Based on an
} Inorganic Complexing Agent

\author{
Masoud Rafizadeh, ${ }^{a}$ Majid Bahmani, ${ }^{b, *} \operatorname{Reza}$ T. Chelaras ${ }^{\mathrm{a}}$ \\ a) Department of Chemistry, University of Tarbiat Moalem, Shahid Mofateh Street, Tehran, Iran \\ ${ }^{b)}$ Research Institute of Petroleum Industry, Catalyst Division, P.O. Box: 18745-4163, \\ Pazhooheshgah Blvd. Khairabad, Old Qom Road, Tehran, Iran
}

Received 25 September 2004; accepted October 2006

\begin{abstract}
A new alkaline electrolytic solution based on ammonia for copper electroplating has been investigated. Upon addition of alkaline metal hydroxide solution and ammonia followed by the immediate addition of a strong inorganic acid, a highly exothermic reaction takes place. At optimum solution condition ammonia remains in solution as $\mathrm{NH}_{2}$ and forms a complexing agent.
\end{abstract}

Keywords: copper electroplating, alkaline bath, non-cyanide.

\section{Introduction}

Electroplating of copper from cyanide solutions is a long-established industrial practice [1-9]. Despite the good adherence, brightness and colour hazardous issues has resulted in search for an alternative to the cyanide solutions. Some of the alternative electrolytes used in the previous works include EDTA [10-14], citrate [15], fluoroborate [6], acid sulphate [16-18] and pyrophosphate [19].

Indeed some of these electrolytic solutions ("electrolytes") such as sulphuric acid, citric acid, acetic acid and fluoroboric acid have been used commercially. There are also available some non-cyanide commercial alkaline solutions which utilise chelating ligands such as carboxylates, phosphates and amines. In contrast to acidic non-cyanide solutions these solutions need no pretreatment in a cyanide solution (Tables 1 and 2).

In this paper, a new alkaline solution based on ammonia as the ligand is presented.

The new ammonia-based solution studied in this work is based on the findings by McCoy et al. [20] in a U.S. patent article. It is reported in this article that when the addition of solution of ammonium hydroxide to an alkaline metal hydroxide solution is followed by the immediate addition of a strong inorganic acid, a highly exothermic reaction takes place. In this reaction, ammonia is not evolved

\footnotetext{
*Corresponding author. E-mail address: bahmani61@yahoo.com
} 
but rather stays in solution as $\mathrm{NH}_{2}$ and forms complexes with metal ions in solution.

The results of copper electroplating in the new alkaline solution were compared with the results in commercial high speed/high efficiency cyanide solutions.

Table 1. Typical acidic non-cyanide electrolytic solutions.

\begin{tabular}{|c|c|c|}
\hline Bath & Advantages & Disadvantages \\
\hline Copper fluoroborate & $\begin{array}{c}\text { Control of bath is easy, wide } \\
\text { values of concentration, } \\
\text { temperature, current and pH } \\
\text { can be used }\end{array}$ & $\begin{array}{c}\text { Steel cathodes need } \\
\text { pretreatment in cyanide bath, } \\
\text { filtration of bath is necessary }\end{array}$ \\
\hline Copper sulphate & $\begin{array}{c}\text { Suitable for lead and nickel } \\
\text { cathodes }\end{array}$ & $\begin{array}{c}\text { Not suitable for iron and } \\
\text { aluminium cathodes, } \\
\text { pretreatment with a cyanide } \\
\text { bath is necessary }\end{array}$ \\
\hline
\end{tabular}

Table 2. Typical alkaline non-cyanide electrolytic solutions.

\begin{tabular}{|c|c|c|}
\hline Bath & Advantages & Disadvantages \\
\hline Amine & $\begin{array}{c}\text { Good deposit thickness, no } \\
\text { wetting agent required }\end{array}$ & $\begin{array}{c}\text { PH control is very important, } \\
\text { electrodes dissolve in the } \\
\text { bath so they must be taken } \\
\text { out when not in use }\end{array}$ \\
\hline Pyrophosphate & $\begin{array}{c}\text { Non toxic, neutral pH, good } \\
\text { for plating on steel }\end{array}$ & $\begin{array}{c}\text { Not suitable for plating on } \\
\text { zinc, pH control is necessary }\end{array}$ \\
\hline
\end{tabular}

\section{Experimental procedure}

All chemicals were analytical grades. A $(1 \times 1) \mathrm{cm}^{2}$ iron plate with a thickness of $1 \mathrm{~mm}$ as cathode and a $(1 \times 2) \mathrm{cm}^{2}$ copper plate as anode, $1 \mathrm{~cm}$ apart, were placed in a $25 \mathrm{~cm}^{3}$ beaker.

Current and voltage were measured using a FLUKE digital multimeter and a rectifier was used as the source of direct current. Thickness of the deposited layer was measured by taking Scanning Electron Microscopy photographs.

Prior to using in the solution the surfaces of iron plates were sand papered using sand papers of increasing fineness $(88 \mu \mathrm{m}$, then $18 \mu \mathrm{m}$, and then $8 \mu \mathrm{m})$. The surfaces were then cleansed of grease using a solution made up of $30 \mathrm{~g}$ washing powder, $5 \mathrm{~g}$ texaphone, $15 \mathrm{~g} \mathrm{Na}_{3} \mathrm{PO}_{4}, 30 \mathrm{~g} \mathrm{Na}_{2} \mathrm{CO}_{3}$ and $15 \mathrm{~g} \mathrm{NaOH}$ made up to $1000 \mathrm{~cm}^{3}$. The cleansing solution was heated to $70-90{ }^{\circ} \mathrm{C}$ into which iron plates were immersed.

First solutions were prepared to observe the claimed complex formation according to the procedure described by McCoy et al. [20]. First an alkaline solution (I) was prepared using ammonia and potassium hydroxide of different concentrations and the resulting solution was cooled to $5{ }^{\circ} \mathrm{C}$. Then an acid solution (II) was prepared using different inorganic acids and left to cool down. Then the acid solution (II) was poured suddenly into the alkaline solution (I) and the resulting solution was stirred magnetically until it reached room temperature. 
Different concentrations of ammonia, potassium hydroxide, sodium hydroxide and also different types of acid such as phosphoric acid, nitric acid and hydrochloric acid, were used as shown in Table 3.

Conventional chemistry predicts that addition of a strong acid solution to a strong alkaline solution produces the precipitation of a salt and also evolution of ammonia is observed. For example addition of phosphoric acid to ammonia produces ammonium di-phosphate and also ammonia is evolved. As addition of a strong acid to a strong alkaline solution produces a buffer solution, the resulting solution was also tested for its buffer properties. It can be seen that solutions c6c9, c12-c14 and c16 do not indicate observable changes and additionally $\mathrm{pH}$ remains neutral.

Table 3. Experimental schemes to verify complex formation.

\begin{tabular}{|c|c|c|c|c|c|c|c|}
\hline Observation & $\mathrm{pH}$ & \multicolumn{2}{|c|}{ Solution (II) } & \multicolumn{3}{|c|}{ Solution (I) } & \multirow[b]{2}{*}{$\begin{array}{c}\text { Solution } \\
\text { name }\end{array}$} \\
\hline & & $\begin{array}{l}\mathrm{H}_{2} \mathrm{O} \\
(\mathrm{mL})\end{array}$ & $\begin{array}{l}\text { Acid } \\
(\mathrm{mL})\end{array}$ & $\begin{array}{l}\mathrm{H}_{2} \mathrm{O} \\
(\mathrm{mL})\end{array}$ & $\begin{array}{c}\text { Alkali } \\
(\mathrm{mL})\end{array}$ & $\begin{array}{l}\mathrm{NH}_{3} \\
(\mathrm{~mL})\end{array}$ & \\
\hline & 2 & 2 & 4 & & 3 & 2 & $\mathrm{C} 1$ \\
\hline $\begin{array}{l}\text { Precipitate } \\
\text { formed }\end{array}$ & 3 & 2 & 4 & 1 & 3 & 2 & $\mathrm{C} 2$ \\
\hline \multirow[t]{2}{*}{$\begin{array}{c}\text { Precipitate } \\
\text { formed }\end{array}$} & 4 & 2 & 4 & 2 & 3 & 2 & $\mathrm{C} 3$ \\
\hline & 7 & 3 & 3 & 2 & 3 & 2 & $\mathrm{C4}$ \\
\hline \multirow[t]{6}{*}{$\begin{array}{l}\text { Ammonia } \\
\text { released }\end{array}$} & 11 & 3.5 & 4 & 2 & 3 & 2 & $\mathrm{C} 5$ \\
\hline & 6 & 2 & 4 & & 4 & 2 & C6 \\
\hline & 6 & 2 & 4 & & 3 & 3 & C7 \\
\hline & 7 & 2 & 4 & 2 & 3 & 3 & $\mathrm{CB}$ \\
\hline & 7 & 2 & 4 & & 3 & 4 & $\mathrm{Cg}$ \\
\hline & 8 & 2 & 3 & & 3 & 4 & $\mathrm{C} 10$ \\
\hline \multirow[t]{4}{*}{$\begin{array}{l}\text { Ammonia } \\
\text { released }\end{array}$} & 10 & 2 & 4 & & 3 & 4 & C11 \\
\hline & 8 & 1 & 5 & & 3 & 4 & $\mathrm{C} 12$ \\
\hline & 8 & 2 & 5 & & 3 & 5 & $\mathrm{C} 13$ \\
\hline & 7 & 2 & 5 & & 3 & 5 & C14 \\
\hline \multirow[t]{3}{*}{$\begin{array}{l}\text { Ammonia } \\
\text { released }\end{array}$} & 9 & 2 & 5 & & 3 & 5 & $\mathrm{C} 15$ \\
\hline & 8 & 2 & 4 & & 3 & 5 & $\mathrm{C} 16$ \\
\hline & 1 & 2 & 5 & 3 & 3 & 2 & $\mathrm{C} 17$ \\
\hline $\begin{array}{l}\text { Ammonia } \\
\text { released }\end{array}$ & $>11$ & 2 & 4 & 3 & 3 & 2 & C18 \\
\hline
\end{tabular}

The following tests were carried out further to verify complex formation in the solution:

- buffer properties;

- effect of change in temperature;

- effect of addition of hydrogen peroxide;

- effect of the presence of different metallic ions in solution such as Fe, cobalt and copper;

- effect of increase of copper concentration in solution. 
After preliminary experiments to check for the above effects the baths shown in Table 4 at a $\mathrm{pH}$ of 8 were prepared.

Table 4. Optimised bath formulation used for electroplating.

\begin{tabular}{|c|c|c|c|c|c|}
\hline \multicolumn{3}{|c|}{ Solution (II) } & \multicolumn{2}{c|}{ Solution (I) } & \multirow{2}{*}{$\begin{array}{c}\text { Solution } \\
\text { number }\end{array}$} \\
\hline $\mathrm{Cu}^{\prime}(\mathrm{mL})$ & $\mathrm{H}_{2} \mathrm{O}(\mathrm{mL})$ & Acid $(\mathrm{mL})$ & Alkali (mL) & $\mathrm{NH}_{3}(\mathrm{~mL})$ & E1 \\
\hline 1 & 1 & 4 & 3 & 4 & E2 \\
\hline 1 & 1 & 4 & 3 & 4 & E3 \\
\hline 1 & 1 & 5 & 3 & 4 & E4 \\
\hline 1 & 1 & 5 & 3 & 5 & \\
\hline
\end{tabular}

Copper electroplating at a voltage of $6 \mathrm{~V}$ and current of $670 \mathrm{~mA}$ was carried out. Solutions E1 and E3 did not produce a good deposit layer but solutions E2 and E4 produced good deposit layer with the colour of deposit in solution E4 better than in solution E2. Following these results, solution E4 was used as the main formulation and experiments were carried out to optimise the electroplating conditions.

Table 5. Effect of various experimental conditions on the optimized bath formulation.

\begin{tabular}{|c|c|c|c|c|c|}
\hline Observation & $\begin{array}{c}\text { Current } \\
(\mathrm{mA})\end{array}$ & $\begin{array}{c}\text { Voltage } \\
(\mathrm{V})\end{array}$ & $\begin{array}{c}\text { Time } \\
(\mathrm{s})\end{array}$ & $\begin{array}{c}\text { Temp. } \\
\left({ }^{\circ} \mathrm{C}\right)\end{array}$ & Solution \\
\hline $\begin{array}{c}\text { Good deposit and colour, blue } \\
\text { precipitate on anode }\end{array}$ & 670 & 6 & 60 & 45 & $15 \mathrm{~mL} \mathrm{E4}$ \\
\hline $\begin{array}{c}\text { Medium deposit and colour, blue } \\
\text { precipitate on anode }\end{array}$ & 500 & 6 & 60 & 45 & $7.5 \mathrm{~mL} \mathrm{E4,}$ \\
\hline $\begin{array}{c}\text { Bad deposit and colour, blue } \\
\text { precipitate on anode }\end{array}$ & 470 & 6 & 60 & 45 & $\begin{array}{c}14 \mathrm{~mL} \mathrm{H} \text {. } 4 \\
1 \mathrm{~mL} \mathrm{NH}\end{array}$ \\
\hline $\begin{array}{c}\text { Good deposit and excellent colour, } \\
\text { blue precipitate on anode }\end{array}$ & 650 & 6 & 60 & 50 & $15 \mathrm{~mL} \mathrm{E4}$ \\
\hline $\begin{array}{c}\text { Bad deposit and colour, blue } \\
\text { precipitate on anode }\end{array}$ & 390 & 6 & 60 & 70 & $15 \mathrm{~mL} \mathrm{E4}$ \\
\hline $\begin{array}{c}\text { Good deposit and dark colour, low } \\
\text { precipitate on anode }\end{array}$ & 670 & 6 & 60 & 45 & $15 \mathrm{~mL} \mathrm{E4}$ \\
\hline
\end{tabular}

Following these results the best formulation is therefore:

Table 6. Proposed formulation for copper electroplating bath.

\begin{tabular}{|c|c|c|c|c|c|}
\hline $500 \mathrm{~mL} \mathrm{NH}_{3}$ & $\begin{array}{c}200 \mathrm{mg} \\
\text { Alkaki }\end{array}$ & $50 \mathrm{~mL}$ Acid & \multicolumn{2}{|c|}{$200 \mathrm{~mL}$ water } & $\begin{array}{c}10 \mathrm{~g} \\
\text { copper } \\
\text { sulphate }\end{array}$ \\
\hline $\begin{array}{c}\text { Temperature }=25-40 \\
{ }^{\circ} \mathrm{C}\end{array}$ & $\begin{array}{c}\text { Voltage }=6 \\
\mathrm{~V}\end{array}$ & $\begin{array}{c}\text { Time=maximum } 2 \\
\text { minutes }\end{array}$ & $\begin{array}{c}\text { Current }=670 \\
\mathrm{~mA}\end{array}$ & $\begin{array}{c}\text { Steel } \\
\text { anode }\end{array}$ & \\
\hline
\end{tabular}


The results of electroplating in this new bath were compared with the results in a high speed/high efficiency cyanide bath as suggested in [21]. The high speed/high efficiency bath was prepared as follows: $9.4 \mathrm{~g}$ potassium cyanide was weighed and dissolved in $40 \mathrm{~mL}$ of distilled water with $6 \mathrm{~g}$ of copper.

Table 7. Comparison of the new bath with high speed/high efficiency cyanide bath.

\begin{tabular}{|c|c|c|}
\hline $\begin{array}{c}\text { Ammonia based } \\
\text { bath }\end{array}$ & $\begin{array}{c}\text { High speed/high } \\
\text { efficiency cyanide } \\
\text { bath }\end{array}$ & $\begin{array}{c}\text { Deposit layer and bath } \\
\text { condition }\end{array}$ \\
\hline Strong & Strong & Deposit layer colour \\
\hline $2 \mu \mathrm{m}$ and uniform & $\begin{array}{c}3-4 \mu \mathrm{m} \text { and non- } \\
\text { uniform }\end{array}$ & $\begin{array}{c}\text { Deposit layer thickness } \\
\text { (for same deposition } \\
\text { time) }\end{array}$ \\
\hline Blue & Transparent & Bath colour \\
\hline None & Some & $\begin{array}{c}\text { Particulate matter in the } \\
\text { bath }\end{array}$ \\
\hline Copper is not usable & Copper & Anode type \\
\hline $670 \mathrm{~mA}$ & $350 \mathrm{~mA}$ & Current \\
\hline Stable & Unstable & Bath stability with time \\
\hline Cheap & Expensive & Cost \\
\hline
\end{tabular}

Cyanide was added to this solution and then $1.5 \mathrm{~g}$ potassium carbonate and $4.3 \mathrm{~g}$ sodium hydroxide were added to this solution. The solution was made up to a volume of $100 \mathrm{~mL}$ with distilled water. $15 \mathrm{~mL}$ of the resulting solution were placed in a $25 \mathrm{~mL}$ beaker and the iron and copper plates were placed in the bath. A voltage of $6 \mathrm{~V}$ and current of $500 \mathrm{~mA}$ was applied to the plates and a temperature of $70{ }^{\circ} \mathrm{C}$ was maintained in the bath. After several experiments, and examination of deposit layer, it was decided to add $4 \mathrm{~mL}$ of brightening agent and $8 \mathrm{~mL}$ of co-brightening agent to the bath. Scanning Electron Microscopy revealed a deposit layer thickness of 3-4 $\mu \mathrm{m}$ with good colour.

\section{References}

1. V.A. Lamb, D.R. Valentine, Plating 52 (1965) 1289.

2. V.A. Lamb, D.R. Valentine, Plating 53 (1966) 86.

3. V.A. Lamb, D.R. Valentine, C.E. Johnson, J. Electrochem. Soc. 117 (1970) C291, C341.

4. U. Bertoucci and D.R. Turner, in A.J. Bard (Ed.), 'Encyclopedia of Elements', (1974) II-6, p. 465.

5. F.A. Lowenheim. "Modern Electroplating", John Wiley \& Sons, New York, 1974.

6. N.V. Parthasaradhy, "Practical Electroplating", Practice Hall, NJ, 1989.

7. D. Chu, P.S. Fedkiw, J. Electroanal. Chem. 345 (1993) 107.

8. R.E. Sinitski, V. Srinivasan, R. Haynes, J. Electrochem. Soc. 127 (1980) 47.

9. J. Horner, Plat. Surf. Finish. 85 (1998) 42. 
10. R.Y. Ying, R. Moy, L.C. Fraser, S. O'Bannion, F.M. Donahue, J. Electrochem. Soc. 135 (1988) 654.

11. F.M. Donahue, J. Electrochem. Soc. 127 (1980) 51.

12. F.M. Donahue, K.L.M. Wong, R. Bhala, J. Electrochem. Soc. (1980) 2340.

13. F.M. Donahue, D.J. Sajkowski, A.C. Bosio, L.L. Schafer, J. Electrochem. Soc. 129 (1982) 717.

14. M. Matsuoka, J. Murai, C. Iwakura, J. Electrochem. Soc. 139 (1992) 2466.

15. V. Alvarez, S. Gonzalez, A. Arevalo, Electrochim Acta 29 (1984) 1187.

16. D. Stoychev, C. Tsvetanov, J. Appl. Electrochem. 26 (1996)

17. J.C. Fabricius, K. Kontturi, G. Sundholm, J. Appl. Electrochem. 26 (1996) 1179.

18. Y. Shingaya, H. Matsumoto and M. Ito, Surf. Sci. 335 (1995).

19. V.A. Lamb, D.R. Valentine and C.E. Johnson, J. Electrochem. Soc. 117 (1970) C291, C341.

20. L.G. Durney. "Electroplating Engineering Handbook", 4th edition, 1984.

21. McCoy, U.S. Patent, 2,411, 674, 1946. 